\title{
Company Profitability Performance in Greek Takeover Bids
}

\author{
Ioannis Koutroulis ${ }^{1}$, Panayiotis Alexakis ${ }^{1} \&$ John Mylonakis $^{2}$ \\ ${ }^{1}$ University of Athens, Department of Economics, Greece \\ ${ }^{2} 10$ Nikiforou str., Glyfada, 16675, Athens, Greece \\ Correspondence: Ioannis Koutroulis, University of Athens, Department of Economics, 5 Stadiou str, 10562 , \\ Athens, Greece. E-mail: Iwkoutroulis@yahoo.gr
}

Received: June 20, 2012

Accepted: July 20, 2012

Online Published: July 26, 2012

doi:10.5539/ijef.v4n9p23

URL: http://dx.doi.org/10.5539/ijef.v4n9p23

\begin{abstract}
One of the most studied aspects of Mergers and Acquisitions (M\&A) is their effect both at the time of the announcement and during the period after. Researchers mostly focus on the short-term effects of such agreements, without thoroughly examining the behaviour of shareholders in the long term, namely after conclusion of the agreements. The scope of the paper is to examine the effect of M\&A agreements in the efficiency and overall performance of Greek companies involved in such agreements. This research was based on a sample of 20 announcements made by companies listed in the Athens Stock Exchange and published at the Athens Stock Exchange website during the 2004-2006 period. The evaluation of the Company Performance was carried out with the help of 4 key indicators, like Liquidity, Capital structure, Activity and Performance. Results are in line with previous studies showing that M\&A agreements have a positive effect on the efficiency and overall performance of the companies involved, yet only in the short term; this effect is reversed in the long term, thus creating a negative effect.
\end{abstract}

Keywords: mergers and acquisitions, takeover bids, company performance, stocks returns, profitability, market reactions, investors behavior

JEL Classification Code: G34

\section{Introduction}

One of the most studied aspects of Mergers and Acquisitions (M\&A) is their effect over time. Literature offers several methodologies for determining the successful or unsuccessful result of such agreements, the most important of which is the methodology that focuses on company stock prices before and after the announcement of the agreements, followed by conclusions. This approach is based on the Efficient Market Hypothesis.

Another option would be examining the course of such agreements directly through published Financial Statements of the respective companies. Both methods have advantages and disadvantages: in the first case, it cannot be taken for granted that investors properly incorporate information in stock prices in a timely manner, while in the second case we have no option but to accept the results published by companies as accurate (even though such results may be distorted using "creative accounting" methods).

\section{Past Literature}

\subsection{The Effect of Mergers and Acquisitions in the Short Run}

When it comes to the effect that M\&A agreements have in the short run, literature has demonstrated numerous studies featuring excessive returns for target company shareholders, both at the time of the announcement and during the period that follows (Jensen \& Ruback, 1983; Jarrell, Brickley, \& Netter, 1988). On the other hand, the stock returns of buyers vary and results are often contradictory; there are several studies with positive results (Desai \& Stover, 1985; James \& Weir, 1987; Cornett \& De 1991), while others have shown negative returns (Neely, 1987; Cornett \& Tehranian, 1992).

Among these studies is the one by McGowan and Sulong (2008), who have provided indications to support the view that the announcement of M\&A agreements creates a favourable environment for stock returns. Moreover, Rosen (2006) has asserted that a relationship of direct dependency exists between precedent and current M\&A agreements, as well as a positive correlation between M\&A results and market climate. Kyriazis \& Diakogiannis (2008), in their research studying the course of M\&A agreements in Greece, have reached the conclusion that 
buyers enjoy positive returns of around 4-5\% in average, which are far higher than the ones observed in other countries (where zero or even negative returns have been recorded). For target companies, returns of around 6-11\% have been observed, which are significantly lower than the respective ones seen in other countries. Franks, Broyles \& Hecht (1977) have reached that M\&A agreements yield returns for the shareholders of the companies involved. With respect to the distribution of profits, they have concluded that the largest part, if not the entire amount, ends up with the shareholders of the target company (an increase of approximately $26 \%$ has been observed).

It is generally safe to state that literature mostly suggests a positive progress of M\&A agreements in the short run.

\subsection{The Effect of Mergers and Acquisitions in the Long Run}

Researchers mostly focus on the short-term effects of such agreements, without thoroughly examining the behaviour of shareholders in the long term, namely after conclusion of the agreements. Despite the above, literature has examined the effect of M\&A agreements in the long run, reaching the conclusion that the positive returns gained in the short term tend to become amortised and finally reversed into negative returns. Among the researchers who agree with these results are Asquith (1983), Mueller (1988), and Rau \& Vermaelen (1998). What is puzzling is that researchers find difficulties determining the origin and factors leading up to the above result; a typical example of this question is the outcome of a study by Agrawal, Jaffe \& Mandelker (1992) stating that "the resolution of this anomaly remains a challenge for researchers".

Agrawal, Jaffe \& Mandelker (1992) have recorded a significant decrease in wealth (around 10\%) for the shareholders of the companies involved in merger agreements during the five-year period following their announcement. Kyriazis (2010) has recorded an average of $-2 \%$ in monthly returns for the 3 years following conclusion of the agreements. In addition to the above, Hogarty (1970) has concluded that the companies that use $M \& A$ agreements as their primary means of growth gain less returns than the average number of companies within their sector.

Another study with similar results is that of Dickerson, Gibson \& Tsakalotos (1997), in which no evidence has been found to support the view that M\&As have a positive impact on company performance. To the contrary, they have reached the conclusion that not only M\&A-based growth has a weaker effect than internal growth methods (a result reached through comparisons performed with companies not involved in M\&A agreements), but also that M\&As literally reduce company profitability. Finally, Rosen (2006) has compared short term and long term returns for such agreements and has claimed that short-term results are amortised in the long term; this may be an indication that, over time, the market is possibly counterbalancing short-term returns that were due to excessive optimism.

In conclusion, the majority of studies reach the result that the course of M\&A agreements in the long term is negative. In their study, Rosa, Engel, Moore \& Woodliff (2003) have attempted to explain the factors that affect the agreements' long term outcome, resulting in the view that the negative returns observed in the long run are due to the fact that company managers choose to withhold and not publish unfavourable information.

\section{Research and Methodology}

\subsection{Sample}

The study sample is based on the announcements made by companies listed in the Athens Stock Exchange and published at the Athens Stock Exchange website (www.ase.gr) during the 2004-2006 period; this is a period of extensive rise in the number of M\&A agreements (the second period being that between 1998-2000). It contains 20 agreements concluded among Greek companies, which were completed in the above period and with which the buyers obtained over $50 \%$ of the target company in each case.

All buyers are companies trading in the Athens Stock Exchange, while our sample contains both agreements among listed companies and agreements between listed and non-listed companies. Finally, the sample includes both agreements that have been funded in cash as well as in shares. Participating companies represent all economic sectors, except those of Finance and Banking. These sectors that sample companies belong to are shown in Table 1. 
Table 1.

\begin{tabular}{l|l}
\hline 1 & Chemicals - Specialty Chemicals \\
\hline 2 & Oil \& Gas - Vertically Integrated Companies Producing Oil \& Natural Gas \\
\hline 3 & Technology - Internet \\
\hline 4 & Chemicals - Commodity Chemicals \\
\hline 5 & Foods \& Beverage - Farming \& Fishing \\
\hline 6 & Constructions \& Materials - Building Materials \& Fixtures \\
\hline 7 & Industrial Goods \& Services - Industrial Suppliers \\
\hline 8 & Technology - Computer Services \\
\hline 9 & Personal \& Household Goods - Durable Household Products \\
\hline 10 & Personal \& Household Goods - Clothing \& Accessories \\
\hline 11 & Basic Resources - Nonferrous Metals \\
\hline 12 & Retail- Specialty Retail \\
\hline 13 & Media - Broadcasting \& Entertainment \\
\hline
\end{tabular}

\subsection{Research Methodology}

The evaluation of the Efficiency and Performance of these companies shall take place with the help of indicators that reflect the companies' financial status. The indicators used are described in detail in Table 2.

Table 2.

\begin{tabular}{ll}
\hline indicators & calculation method \\
\hline $\begin{array}{l}\text { liquidity indicators } \\
\text { general liquidity } \\
\text { cash liquidity }\end{array}$ & $\begin{array}{l}\text { circulating assets/ short term liabilities } \\
\text { (circ. assets - reserve)/ short term liabilities }\end{array}$ \\
\hline $\begin{array}{l}\text { capital structure indicators } \\
\text { total debt ratio }\end{array}$ & $\begin{array}{l}\text { loan obligations/ assets } \\
\text { profits before interest \& taxes/ interests }\end{array}$ \\
financial costs coverage by operating profits & \\
activity indicators & sales cost/ average stock \\
circulatory speed of stock & sales/assets \\
circulatory speed of assets & claims/ (sales/360) \\
days sales outstanding & \\
\hline performance indicators & profits before taxes/ sales \\
net profit margin & profits before taxes/ equity \\
return on equity & profits before taxes/ assets \\
return on invested capital & \\
\hline
\end{tabular}

The followed methodology is based on the examination of the above indicators and their progress during the 3 -year period that follows the conclusion of the agreement. With the help of indicators, we are able to examine the effect of such agreements on several aspects of corporate economic performance, such as liquidity, capital structure, circulatory speed and company efficiency.

More specifically, the applied methodology is based on the comparison of indicators and their progress during the 3-year period mentioned above. Firstly, the indicators for the first year are calculated for each agreement within the sample (namely the year when the agreement was completed); following that, the indicators corresponding to the subsequent three years following completion of the agreement are also calculated. Next, the differences in these indicator values are measured, using the first year (that is the year when the agreement was completed) as reference. These differences represent the progress of the agreements. These differences in values then become the scope of our study and they are used to perform statistical tests, which can then accurately provide insight on the progress of agreements in the short and the long run. This method is also used to examine the impact of these agreements on various economic aspects of the companies involved, as well as any existing relations between them. However, in order to establish completeness in our study and ensure that its results are accurate, it is essential that we compare the results deducted on the progress of companies involved in agreements with the results from companies that have not engaged in M\&A agreements. Only then will one be able to ascertain whether M\&As have a positive or negative impact on companies. 
For this reason, we have taken a sample of companies of the same sector as the ones in our first sample, which are trading in the Athens Stock Exchange and which were not involved in M\&A agreements for the same time period (2004-2006). It is the case however that our first sample includes some companies for which no corresponding companies were found that were not engaged in M\&As. This is due to the fact that these companies belong to sectors that are strongly dependent on Mergers and Acquisitions to achieve growth, such as the sector of "Foods \& Beverage - Farming \& Fishing". The second sample consists of 10 companies not engaged in M\&A agreements, which are matched with those included in our first sample. The sectors represented by companies of our second sample are shown in Table 3 .

Table 3.

\begin{tabular}{l|l}
\hline 1 & Chemicals - Specialty Chemicals \\
\hline 2 & Oil \& Gas - Vertically Integrated Companies Producing Oil \& Natural Gas \\
\hline 3 & Constructions \& Materials - Building Materials \& Fixtures \\
\hline 4 & Industrial Goods \& Services - Industrial Suppliers \\
\hline 5 & Technology - Computer Services \\
\hline 6 & Personal \& Household Goods - Durable Household Products \\
\hline 7 & Personal \& Household Goods - Clothing \& Accessories \\
\hline 8 & Retail- Specialty Retail \\
\hline 9 & Media - Broadcasting \& Entertainment \\
\hline
\end{tabular}

The final part of the study makes direct comparison between the progress made by companies comprising both our samples in the short term and the long term. This comparison is carried out per indicator category and is followed by final synopsis and conclusions.

At this point, it is important to provide some reference on the methodology used for the above comparison of our two samples. Firstly, comparison is performed for each indicator separately with respect to the changes recorded since the reference year both in the short and the long run. Such comparison is made possible with the help of hypothesis testing, in order to ascertain which of the two samples (those including companies involved and companies not involved in M\&A agreements) presents higher returns during the examined period. The first step is to discover the type of distribution followed by our data, which can be done using the Kolomogorov-Smirnov test. The Kolomogorov-Smirnov test examines the following two hypotheses: H0 indicates that a normal distribution is followed, whereas $\mathrm{H} 1$ indicates that our data does not follow a normal distribution. The answer to the question of normality depends on the p-value of our test: if p-value $>$ 1 -confidence level (in our case, the level of confidence is 95\%) we then accept H0; if not, H0 is rejected. Depending on the distribution followed by our sample, we then apply the appropriate hypothesis test (parametric or non-parametric). The hypothesis tests applied on our study samples examine the differences between either the mean value (parametric tests, such as $t$-test), or the median (non-parametric tests, such as the Wilcoxon Signed Rank Test). They can show precisely which one of the two samples presents higher performance for the examined period. This test offers an insight as to which companies have had the best performance, which can lead us to the answer regarding whether M\&A agreements have a positive or negative impact on the efficiency and overall performance of those companies involved.

\section{Research Results}

\subsection{Results on the Progress of Companies Involved in M\&A Agreements}

First of all, tables are created containing all indicators for each company and year; based on these tables, the differences between indicators per year are then calculated, always using the first year as base year (that is the year when the agreement was completed). Hypothesis tests are then performed, which can describe in detail the effect that these agreements had on the efficiency and performance of companies. The following tables contain the data for indicator changes of those companies involved in M\&As during the period under examination (short-term and long-term). 
Table 4. Table showing the progress of companies involved in M\&As

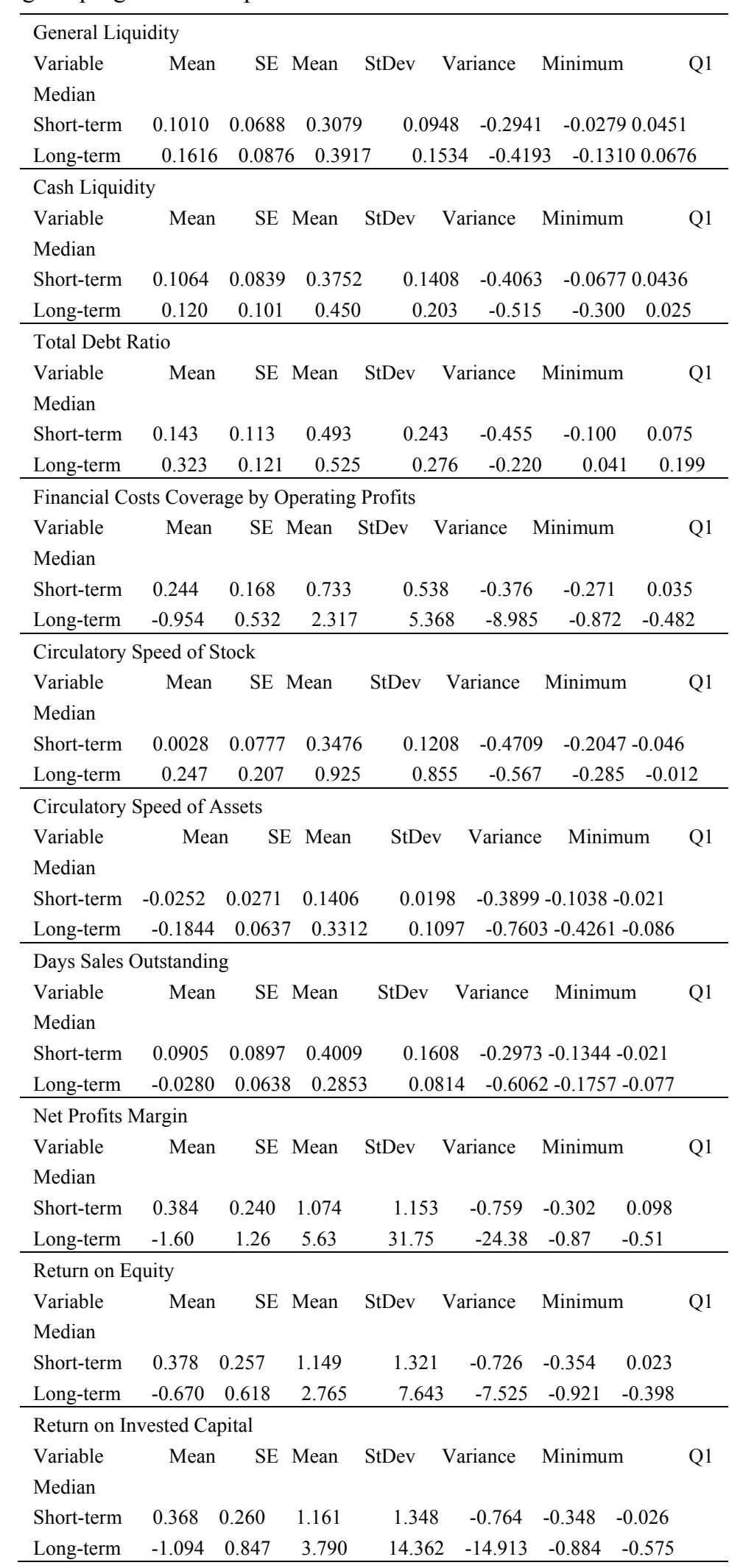

By summarizing the results of indicator progress during the 3-year period following conclusion of the agreements, result are shown in Table 5, which describes the changes in indicator values. 
Table 5 .

\begin{tabular}{lll}
\hline Indicators & Short-term & Long-term \\
\hline Liquidity & & \\
General liquidity & $10 \%$ & $16 \%$ \\
Cash liquidity & $10 \%$ & $12 \%$ \\
Capital structure & & \\
Total debt ratio & $14 \%$ & $30 \%$ \\
Financial needs coverage & $24 \%$ & $-95 \%$ \\
Activity & & \\
Circulatory speed of stock & $0.20 \%$ & $24 \%$ \\
Circulatory speed of assets & $-2 \%$ & $-2 \%$ \\
Days sales outstanding & $9 \%$ & $-2 \%$ \\
Performance & & \\
Net profit margin & $38 \%$ & $-160 \%$ \\
Return on equity & $38 \%$ & $-67 \%$ \\
Return on invested capital & $36 \%$ & $-100 \%$ \\
\hline
\end{tabular}

From the results of the statistical research on the sample of Greek companies involved in M\&A agreements between years 2004 and 2006, numerous conclusions are drawn regarding their Efficiency and Performance both in the short and the long term. Overall, both Efficiency and overall Performance of companies in the short run has improved to an extent that is statistically significant.

However, the positive effect is reversed in the long term, and the primary aspects of corporate economic performance decline. These results are in line with the results of other studies that examine the Effectiveness of Merger and Acquisition agreements (based on the performance of company stocks); these studies have recorded a positive course in the short term which is reversed in the long term both for Greek companies (Kyriazis, 2010), as well as, for Companies listed in foreign stock markets (Agrawal, Jaffe, Mendelker, 1992; Asquith, 1983) etc.

\subsection{Results on the Progress of Companies Not Involved in M\&A Agreements}

Following the same methodology as the one used in the first sample, below is Table 6 containing the data for indicator changes of companies not involved in M\&As during the period under examination (short-term and long-term). 
Table 6. Tables showing the progress of companies not involved in M\&As

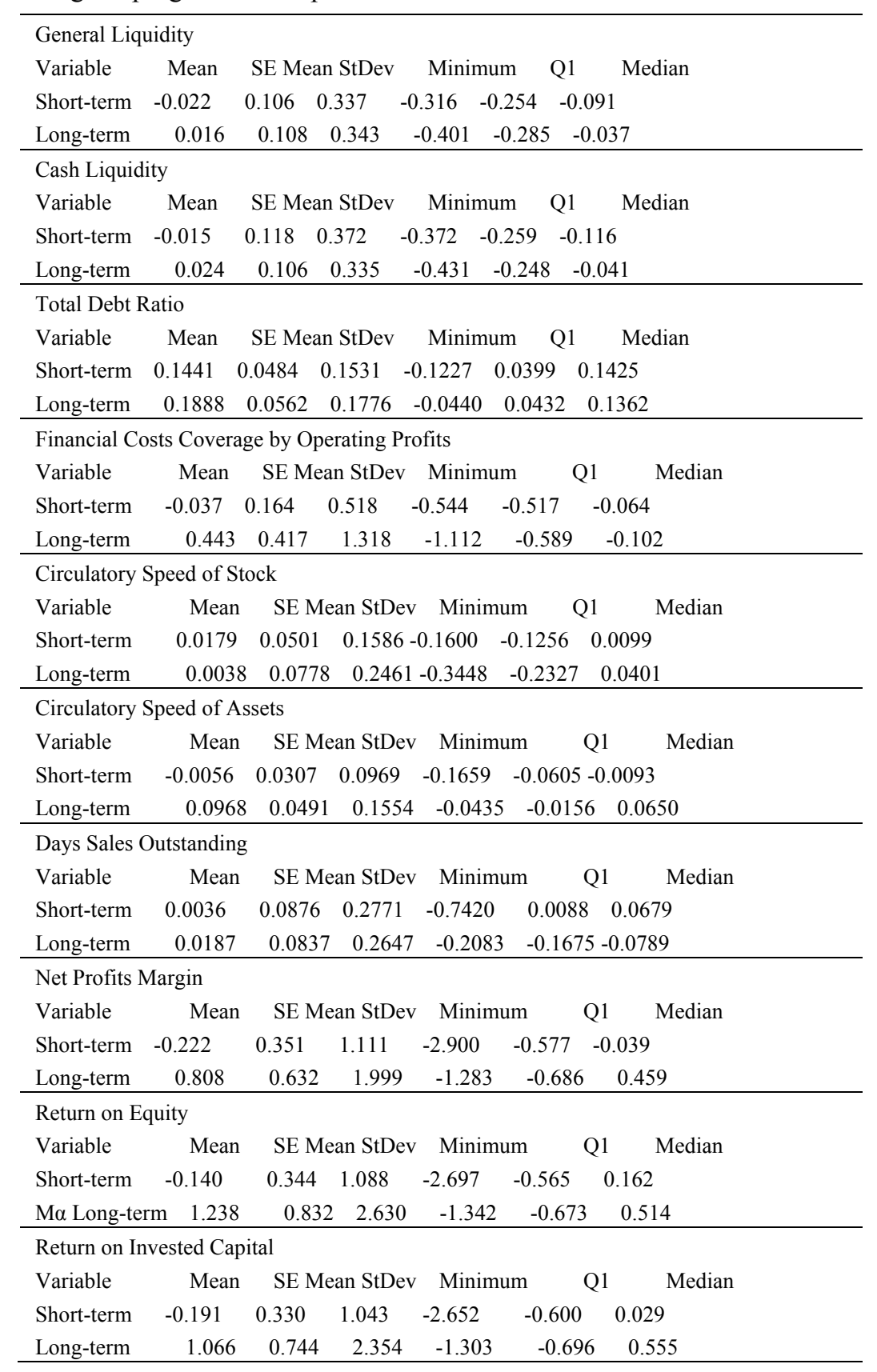

By summarizing the results of indicator progress during the 3-year period following the conclusion of the agreements, result are shown in Table 7, which describes the changes in indicator values. 
Table 7.

\begin{tabular}{lll}
\hline Indicators & Short-term & Long-term \\
\hline Liquidity & $-2 \%$ & \\
General liquidity & $-2 \%$ & $2 \%$ \\
Cash liquidity & & $2 \%$ \\
Capital structure & $14 \%$ & $18 \%$ \\
Total debt ratio & $-4 \%$ & $44 \%$ \\
Financial needs coverage & & \\
Activity & $2 \%$ & $0.30 \%$ \\
Circulatory speed of stock & $-1 \%$ & $10 \%$ \\
Circulatory speed of assets & $0 \%$ & $2 \%$ \\
Days sales outstanding & & \\
Performance & $-22 \%$ & $80 \%$ \\
Net profit margin & $-14 \%$ & $120 \%$ \\
Return on equity & $-19 \%$ & $100 \%$ \\
Return on invested capital & & \\
\hline
\end{tabular}

From the results of the statistical research on the second sample (that of Greek companies not involved in M\&A agreements between years 2004 and 2006), we may draw numerous conclusions regarding their Efficiency and Performance both in the short and the long term.

Overall, both Efficiency and company Performance has declined in the short term, yet this negative course is reversed in the long term, and the most basic aspects of corporate economic performance improve to a statistically significant extent. These results are in line with the results of other studies (Hogarty, 1970; Dickerson, Gibson \& Tsakalotos, 1997) who, having examined company performance, have reached that in the long term companies that do not choose to grow through Mergers \& Acquisitions obtain better results.

\subsection{Conclusions from the Comparison of Companies Involved in M\&As with Those Not Involved in M\&As}

At this point, having examined company progress for our two samples separately, and in order to finalise our research, we shall proceed with directly comparing the progress of companies involved in M\&A agreements with those not involved (Table 8).

Table 8.

\begin{tabular}{lll}
\hline Indicators & Short-term & Long-term \\
\hline Liquidity & & \\
General liquidity & Involved & Involved \\
Cash liquidity & Involved & Involved \\
Capital structure & & \\
Total debt ratio & Involved & Not involved \\
Financial needs coverage & Involved & Not involved \\
Activity & & \\
Circulatory speed of stock & Not involved & Involved \\
Circulatory speed of assets & Not involved & Not involved \\
Days sales outstanding & Involved & Involved \\
Performance & & \\
Net profit margin & Involved & Not involved \\
Return on equity & Involved & Not involved \\
Return on invested capital & Involved & Not involved \\
\hline
\end{tabular}

At this point and following completion of our empirical study on the progress of Greek M\&A agreements, a synopsis of the results is provided from directly comparing companies involved in M\&As with those not involved, and we shall reach a final conclusion on whether such agreements have a positive or a negative effect on companies. The presentation of results shall be based per indicator category and for each indicator separately.

\subsubsection{Liquidity}

With respect to company liquidity, it is observed that both in terms of general and cash liquidity, those companies that have been engaged in M\&As for the entire period examined (both short term and long term) have 
higher performances compared with those that were not engaged in M\&As. With respect to General Liquidity, the companies engaged in $\mathrm{M} \& \mathrm{~A}$ agreements present an increase of $10 \%$ and $16 \%$, while companies not engaged in M\&A agreements present a $2.2 \%$ decline and $1.6 \%$ increase in the short and long term, respectively.

With respect to Cash Liquidity, results are similar: companies engaged in M\&A agreements present an increase of $10 \%$ and $12 \%$, versus a $1.5 \%$ decline and $2.4 \%$ increase for companies not engaged in M\&A agreements in the short and long term, respectively.

From the best performance in liquidity of the companies involved in agreements, it becomes evident that M\&As have had a positive impact on companies in terms of liquidity.

\subsubsection{Capital Structure}

With regard to Capital Structure, it has become clear that companies engaged in M\&As have presented higher performances in the short term, both in terms of Debt Obligations as well as in terms of Financial Costs Coverage by Operating Profits, when compared with those companies not engaged in M\&As. However, this result is reversed in the long-term, and companies not involved in M\&As have better performances over time in both aspects examined above.

Regarding the Total Debt Ratio, both company groups present an increase of $14 \%$ by average in the short term, yet the median of the two samples differs (companies involved in M\&As present an increase of 7\%, while companies not involved in M\&As present an increase of 14\%). In the long term, companies involved in M\&As present an increase in their Debt Obligations by $30 \%$, while on the other hand, companies not involved in M\&As present an increase of around $18 \%$.

On Financial Costs Coverage, the two groups exhibit completely opposite results: companies engaged in M\&As present an increase of $24 \%$ and a decline of $95 \%$, while companies not involved in M\&As present a decline of $3.7 \%$ and an increase of $44 \%$ in the short and long term, respectively.

The above results lead us to the conclusion that M\&A agreements have a positive effect on Capital Structure only in the short term, while they have a negative effect in the long term.

\subsubsection{Activity}

With respect to activity, our results do not follow a specific pattern as happens in other examined parameters. This is due to the fact that activity indicators depend on several corporate aspects which are not fully associated with one another.

Regarding Circulatory Speed of Stock, the two company groups exhibit different performances: more specifically, companies engaged in M\&As present an increase of $0.2 \%$ and $24 \%$, while companies not involved in M\&As present an increase of $1.7 \%$ and $0.3 \%$ in the short and long term, respectively. The above results lead us to the conclusion that M\&A agreements have a negative effect on the Circulatory Speed of Stock only in the short term, while they have a positive effect in the long term.

Regarding Circulatory Speed of Assets, companies engaged in M\&As present a decline of $2 \%$ and $1.8 \%$, while companies not involved in M\&As present a decline of $0.5 \%$ and an increase of $9.6 \%$ in the short and long term, respectively. These results indicate that M\&A agreements have a negative impact on the Circulatory Speed of Assets for companies both in the short and the long term.

With regard to Days Sales Outstanding, we have observed that companies engaged in M\&As present an increase by $9 \%$ and a decline of $2 \%$, while companies not involved in M\&As present an increase of $0.2 \%$ and $9.6 \%$ in the short and long term, respectively. The above results indicate that M\&A agreements have a negative effect on Days Sales Outstanding only in the short term, while they have a positive effect in the long term. However, these results are not statistically significant, because there are large deviations between the average values and medians of our samples.

\subsubsection{Performance}

With respect to Company Performance, all indicators examined follow the same pattern: companies involved in M\&As present higher performances than those not involved in M\&As in the short term. However, this result is reversed in the long term, and companies not involved in M\&As have better performances in all examined indicators.

Regarding Net Profit Margin, the two groups exhibit completely opposite results: companies engaged in M\&As present an increase by $35 \%$ and a decline of $160 \%$, while companies not involved in M\&As present a decline of $22 \%$ and an increase of $80 \%$ in the short and long term, respectively. 
Regarding Return on Equity, the two groups exhibit completely opposite results, as happens above: companies engaged in M\&As present an increase by $37 \%$ and a decline of $67 \%$, while companies not involved in M\&As present a decline of $14 \%$ and an increase of $120 \%$ in the short and long term, respectively.

Regarding Return on Equity, the two groups exhibit completely opposite results, as in the above two cases: companies engaged in M\&As present an increase by $36 \%$ and a decline of $100 \%$, while companies not involved in M\&As present a decline of $19 \%$ and an increase of $100 \%$ in the short and long term, respectively.

The above results lead us to the conclusion that M\&A agreements have a positive effect on company performance only in the short term, while they have a negative effect in the long term.

\section{Conclusions}

On the basis of the results of this study on the course of Greek companies involved in Merger and Acquisition agreements during the 2004-2006 period, it may be regarded that the question raised in this study has been answered, namely "what is the effect of M\&A agreements in the efficiency and overall performance of Greek companies involved in such agreements".

The answer to the above question is that M\&A agreements have a positive effect on the efficiency and overall performance of those companies involved, yet only in the short term; this effect is reversed in the long term, thus creating a negative effect. These results are in line with the results of other studies that examine the Effectiveness of Merger and Acquisition agreements (based on the performance of company stocks); these studies have recorded a positive course in the short term which is reversed in the long term both for Greek companies (Kyriazis, 2010) as well as for Companies listed in foreign stock markets (Agrawal, Jaffe \& Mendelker 1992; Asquith, 1983; Rosen, 2006) etc.

It is also safe to support that, based on the results of this study, the companies not involved in M\&As present higher performances in the long term than those involved in M\&As. These results are in line with the results of other studies (Hogarty, 1970; Dickerson, Gibson \& Tsakalotos, 1997) who, having examined company performance, have reached that in the long term, companies that do not choose to grow through Mergers \& Acquisitions present better performances.

The above bring forward another question, which is the following: "why do companies choose M\&As as a method for growth, since the odds to succeed are against them". A prospective answer to this question has been provided by the study of Hogarty (1970). According to this, there is unequal distribution of profitability, resulting in the majority of investors involved in M\&As not being able to benefit from these profits, while a much smaller percentage of investors gain high returns. This unequal distribution, according to Hogarty, leads investors to conclude M\&A agreements despite their low probability of success. This study demonstrates results that are in line with this view expressed by Hogarty, as our sample of companies involved in M\&As is characterised by high standard deviation and extreme positive observations. Another element in support of this view lies with the distribution followed by our data: it has been observed that in our sample of companies involved in M\&As the distribution of data is abnormal almost in all instances, contrary to our sample of companies not involved in M\&As, where in most cases a normal distribution is followed.

An interesting approach that could become the subject of a future research is to combine the results from published financial statements of companies with the results of stock performance. This way, a future study will be able to thoroughly examine the phenomenon of M\&As in all aspects of company economic performance.

\section{References}

Agrawal, J., Jaffe, J., \& Mandelker G. (1992). The Post-Merger Performance of Acquiring Firms: A Re-examination of an Anomaly. The Journal of Finance, 47(4), 1605-1621.

Dickerson A., Gibson, H., \& Tsakalotos, E. (1997). The Impact of Acquisitions on Company Performance: Evidence from a Large Panel of UK Firms. Oxford Economic Papers, 49(3), 344-361. http://dx.doi.org/10.1093/oxfordjournals.oep.a028613

Firth, M. (1979). The Profitability of Takeovers and Mergers. The Economic Journal, 89(354), 316-328. http://dx.doi.org/10.2307/2231604

Franks, J. R., Broyles, J., \& Hecht, M. J. (1977). An Industry Study of the Profitability of Mergers in the United Kingdom. The Journal of Finance, 32(5), 1513-1525.

Hackbarth, D., \& Morellec, E. (2008). Stock Returns in M\&A. The Journal of Finance, 63(3), 1213-1252. http://dx.doi.org/10.1111/j.1540-6261.2008.01356.x 
Hogarty, T. (1970). The Profitability of Corporate Mergers. The Journal of Business, 43(3), 317-327. http://dx.doi.org/10.1086/295284

Kyriazis, D. (2010). The Long-Term Post Acquisition Performance of Greek Acquiring Firms. International Research Journal of Finance and Economics, 43, 69-79.

Kyriazis, D., \& Diakoyiannis, G. (2008). The Determinants of Wealth Gains in Greek Takeover Bids. International Research Journal of Finance and Economics, 22, 162-177.

Mantravadi, P., \& Reddy, V. (2008). Post-Merger Performance of Acquiring Firms from Different Industries in India. International Research Journal of Finance and Economics, 22, 92-204.

McGowan, C., \& Sulong, Z. (2008). A note on the effect of M\&A Announcements on Stock Price Behavior. International Business \& Economics Research Journal, 31, 211-234.

Rosa, R., Engel, R., Moore, M., \& Woodliff, D. (2003). Post-Acquisition Performance and Analyst Following: US Evidence. UWA Business School University of Western Australia, unpublished paper.

Rosen, R. (2006). Merger Momentum and Investor Sentiment: The Stock Market Reaction to Merger. The Journal of Business, 79(2), 987-1017. http://dx.doi.org/10.1086/499146

Rossi, S., \& Volpin, P. (2004). Cross- Country Determinants of Mergers and Acquisitions. Journal of Financial Economics, 74(2), 277-304. http://dx.doi.org/10.1016/j.jfineco.2003.10.001 